\title{
Perbandingan Metode Microwave Hydrodiffusion and Gravity (MHG) dan Microwave Steam Diffusion (MSDf) untuk Mengekstrak Minyak Atsiri dari Kulit Jeruk (Citrus aurantium L.)
}

\section{Comparison of Microwave Hydrodiffusion and Gravity (MHG) and Microwave Steam Diffusion (MSDf) for Extraction of Essential Oil from Citrus aurantium L. Peel}

\author{
Ayu Chandra Kartika Fitri*, Fikka Kartika Widyastuti \\ Department of Chemical Engineering, Faculty of Engineering, Tribhuwana Tunggadewi University, \\ Jl. Telagawarna Blok C, Tlogomas, Malang, 65144, East Java, Indonesia
}

*Email: ayu.chandra@unitri.ac.id

\begin{abstract}
Abstrak
Produksi jeruk di tahun 2020 diestimasikan mencapai lebih dari 3 juta ton dengan estimasi peningkatan sebesar $5 \%$ per tahun. Akibatnya, kulit jeruk dalam jumlah banyak tersedia sebagai produk sampingan dan diperlakukan sebagai limbah, sehingga dapat menciptakan masalah lingkungan. Permasalahan ini dapat diubah menjadi potensi, jika minyak atsiri dapat diekstraksi dari kulit jeruk. Tujuan penelitian ini untuk membandingkan metode Microwave Hydrodiffusion and Gravity $(M H G)$ dan Microwave Steam Diffusion (MSDf) dalam hal kecepatan waktu ekstraksi, jumlah yield, konsumsi energi listrik, dampak lingkungan (emisi gas CO2) dan komposisi kimianya. Pada penelitian ini digunakan bahan kulit jeruk segar (Citrus aurantium L) 300 gram dengan tiga variasi daya microwave 136 watt, 264 watt, dan 440 watt serta waktu ekstraksi selama 15 menit, 30 menit, 45 menit, dan 60 menit. Metode MSDf menghasilkan yield lebih cepat dibandingkan dengan metode MHG pada daya optimal $264 \mathrm{~W}$. Pada menit ke 20, metode MSDf menghasilkan yield minyak atsiri sebesar 1,95\%, sedangkan metode MHG menghasilkan 1,93\% yield pada menit ke 40 . Metode MSDf meghasilkan jumlah oxygenated compounds $(1,4 \%)$ lebih besar daripada metode MHG (1,12\%). Hasil penelitian menunjukkan bahwa metode MSDf mampu menghasilkan mutu minyak yang baik seperti metode MHG. Berdasarkan perbandingan energi listrik yang dikonsumsi, metode MSDf lebih hemat energi 3\% dibandingkan dengan metode MHG. Emisi Gas $\mathrm{CO}_{2}$ yang dilepas ke udara pada metode MSDf $(0,1368 \mathrm{~kg})$ lebih sedikit daripada metode MHG $(0,14 \mathrm{~kg})$, sehingga dampak ke lingkungan tidak signifikan.
\end{abstract}

Kata kunci : kulit jeruk, minyak atsiri, microwave, MSDf, MHG

\begin{abstract}
Orange production in 2020 projected to reach more than 3.2 million tons, with an estimated growth of $4.93 \%$ per year. As a result, large amounts of orange peel are available as a by-product and are treated as waste, creating environmental problems. This problem can be turned into potential if essential oils can be extracted from orange peels. The purpose of this study is to compare the methods of Microwave Hydrodiffusion and Gravity (MHG) and Microwave Steam Diffusion (MSDf) in terms of extraction time velocity, yield, electricity consumption, environmental impact (CO2 gas emissions) and their chemical composition. In this study, 300 grams of fresh orange peel (Citrus aurantium L) used with three microwave power variations: 136 watt, 264 watt, and 440 watt and extraction time of 15 minutes, 30 minutes, 45 minutes, and 60 minutes. The MSDf method produces yields faster than the MHG method at an optimal power of $264 \mathrm{~W}$. In the 20th minute, the MSDf method produces an essential oil yield of $1.95 \%$, while the MHG method produces $1.93 \%$ yield at the 40th minute. The MSDf method provides the number of oxygenated compounds $(1.4 \%)$ is higher than the MHG method (1.12\%). This study shows that the MSDf method can produce better quality oils as like as the MHG method. Based on the electricity consumed ratio, the MSDf method is 50\% more energy-efficient than the MHG method. Emissions of $\mathrm{CO}_{2}$ gas released into the air in the MSDf method $(0.07 \mathrm{~kg})$ are also less than MHG $(0.14 \mathrm{~kg})$, so the impact on the environment is not too significant.
\end{abstract}




\section{Pendahuluan}

Tanaman jeruk telah lama populer menjadi sumber minyak atsiri, karena mulai dari buah, kulit dan daunnya bisa diekstrak minyaknya. Jeruk adalah tanaman buah terbesar di dunia (100 juta kubik ton per tahun) dan jeruk manis-keprok (Citrus Aurantium) menyumbang $60 \%$ dari produksi buah jeruk [1]. Sedangkan jumlah kulit jeruk yang tersisa sekitar $45 \%$ dari total massa buah jeruk [2]. Buah jeruk menjadi salah satu buah yang diminati oleh masyarakat, karena aromanya menyegarkan, dapat menjadi sumber vitamin $\mathrm{C}$, harga relatif murah, rasanya manis, segar, mudah didapatkan dimana saja dan kapan saja karena ketersediaannya hampir sepanjang tahun. Bahkan produksi buah jeruk di Indonesia menempati peringkat ke-3 dari total produksi buah-buahan di Indonesia. Menurut data Kementerian Pertanian (tahun 2016) produksi jeruk di tahun 2020 diestimasikan mencapai lebih dari 3 juta ton dengan estimasi peningkatan sebesar $4,93 \%$ per tahun. Luas panen komoditas jeruk pada tahun 2020 diestimasi akan mencapai 61.778 hektar dengan pertumbuhan sebesar $2 \%$ per tahun. Pola perkembangan produksi jeruk selama kurun waktu 2010 sampai 2017 cenderung meningkat yaitu pada tahun 2017 produksi jeruk Keprok nasional mencapai lebih dari 2,16 juta ton [3].

Akibatnya, kulit jeruk dalam jumlah banyak tersedia sebagai produk sampingan dan diperlakukan sebagai limbah, sehingga dapat menciptakan masalah lingkungan, terutama pencemaran air, karena adanya biomaterial seperti kandungan minyak atsiri [4]-[6], pectin [2] dan gula. Permasalahan ini dapat diubah menjadi potensi, jika minyak atsiri dapat diekstraksi dari kulit jeruk. Bahkan setelah diekstraksi, kulitnya pun bisa menjadi pakan yang mengandung protein tinggi dalam bentuk kering, selain itu juga meningkatkan keuntungan industri jus jeruk dan mengurangi polusi [2]. Minyak atsiri dari kulit jeruk juga dapat digunakan untuk menambahkan aroma jeruk ke produk-produk seperti minuman berkarbonasi, es krim, kue, dan parfum [7].

Beberapa metode konvensional sudah digunakan untuk mengekstrak minyak atsiri jeruk, seperti metode hydrodistillation, steam distillation, cold pressing, dan solvent extraction. Namun metode konvensional tersebut memiliki kelemahan dalam kualitas produk, yaitu hilangnya beberapa senyawa penting yang volátil, rendahnya efisiensi ekstraksi, konsumsi energi yang besar, waktu proses yang terlalu lama, degradasi senyawa penting dalam minyak akibat pengaruh proses hidrolisis dan pemanasan, dan adanya residu pelarut beracun yang tertinggal dalam ekstrak [8].
Dalam beberapa tahun terakhir telah terjadi peningkatan permintaan proses "green technology" yang baru untuk mengekstrak minyak atsiri, untuk mengurangi dampak lingkungan dan biaya produksi [9]. Oleh karena itu, mulai digunakan teknik ultrasonik dan iradiasi microwave untuk meningkatkan performa proses ekstraksi [10]-[12]. Banyak perhatian telah diberikan pada aplikasi pemanasan dielektrik microwave dalam berbagai proses di industri kimia dan makanan untuk menggantikan metode ekstraktif konvensional. Ekstraksi microwave sekarang dikenal sebagai teknik efisien yang secara dramatis mengurangi waktu ekstraksi (waktu proses yang singkat), minimnya pemakaian solvent/pelarut, meningkatkan yield dan kadar kemurnian/ kualitas produk [4], [13], [14].

Metode yang berhasil dikembangkan untuk ekstraksi minyak atsiri dari kulit jeruk antara lain pada tahun 2006, dikembangkan metode Microwave Clevenger atau Microwave Accelerated Distillation (MAD) yang merupakan kombinasi pemanasan microwave dan distilasi untuk ekstraksi minyak atsiri dari kulit jeruk (Citrus sinensis L.Osbeck, Rutaceae). Metode ini dilakukan pada tekanan atmosfer tanpa menambahkan pelarut atau air. Kemudian MAD dibandingkan dengan teknik konvensional, yang menggunakan alat Clevenger dengan hidro-distilasi (HD). MAD dan HD dibandingkan dalam hal waktu ekstraksi, yield, komposisi kimia, kualitas minyak atsiri, efisiensi dan biaya proses. Ekstraksi dengan MAD lebih hemat dalam konsumsi energi, lebih cepat dalam waktu ekstraksi (30 menit vs 3 jam), lebih banyak fraksi teroksigenasi ( $11,7 \%$ berbanding $7,9 \%)$, yield yang lebih banyak ( $0,42 \%$ berbanding $0,39 \%)$ dan kualitas produk [6].

Selanjutnya, pada tahun 2008 dikembangkan Metode Microwave Hydrodiffusion and Gravity $(M H G)$ yang mengkombinasikan pemanfaatan gravitasi bumi dan pemanasan microwave pada tekanan atmosferik, tanpa penambahan air ataupun pelarut organik. Sehingga cukup memanfaatkan fenomena fisik, hydrodiffusi tanpa destilasi dan evaporasi [13], [15]. Hasilnya pada menit ke 15 didapatkan jumlah yield dan kualitas minyak atsiri yang sama dengan metode konvensional hydrodistillation pada menit ke 90. MHG juga dapat mencegah polusi dengan menghemat energi sebesar 90\% dan mengurangi emisi gas rumah kaca.

Pada tahun 2011, dikembangkan metode Microwave Steam Diffusion (MSDf) untuk mengekstrak minyak atsiri dari kulit jeruk (Citrus sinensis L.Osbeck). Hasilnya kondisi optimal pada laju aliran massa uap $25 \mathrm{~g} / \mathrm{menit}$ dan daya microwave 
$200 \mathrm{~W}$. Minyak atsiri yang diekstrak dengan MSDf selama 12 menit secara kuantitatif dan kualitatif mirip dengan yang diperoleh SDf selama 40 menit. Ekstraksi minyak atsiri dari kulit jeruk dengan MSDf lebih baik daripada SDf dalam hal lebih hemat energi dan berkurangnya limbah cair [16].

Meskipun banyak penelitian telah melaporkan ekstraksi minyak atsiri dari kulit Jeruk, namun tidak ada yang membandingkan ekstraksi berbasis Solvent Free Microwave Extraction (SFME) dengan metode MHG dan MSDf dari kulit jeruk manis (Citrus Aurantium L., Rutaceae). Kedua metode tersebut memiliki keunggulan dibandingkan dengan metode Microwave Accelerated Distillation (MAD), Microwave-Assisted Hydrodistillation (MAHD), Microwave Steam Distillation (MSD), Vacuum Microwave Assisted Extraction (VMAE) seperti memiliki tingkat ekstraksi yang lebih cepat, tidak membutuhkan solvent yang memerlukan pemurnian lanjut, tidak membutuhkan tekanan vakum yang memerlukan peralatan tambahan serta kondisi operasinya tidak perlu sampai kondisi kritis, hemat konsumsi energi, jumlah yield dan kemurniannya lebih tinggi karena tidak memerlukan pelarut sehingga tidak kontak dengan bahan kimia. Oleh karena itu, penelitian ini fokus dalam membandingkan metode MHG dan MSDf dalam hal kecepatan waktu ekstraksi, jumlah yield, konsumsi energi listrik, dampak lingkungan (emisi gas $\mathrm{CO}_{2}$ ) dan komposisi kimianya.

\section{Metodologi Penelitian \\ Bahan}

Jeruk Manis segar (Citrus Aurantium L., Rutaceae) dibeli dari pasar lokal di daerah Dau, kabupaten Malang. Dari berat 1500 gram jeruk manis dikupas kulitnya menghasilkan 20\% (w/w) kulit jeruk, yaitu sekitar 300 gram kulit jeruk dalam kondisi segar dengan kandungan/kadar air sebesar $90 \%$. Kemudian kulit jeruk dicacah menjadi ukuran $\pm 2 \mathrm{~cm}$. Tiap variabel penelitian menggunakan berat 300 gram kulit jeruk dengan rasio F/D (massa bahan dibanding volume distiller round bottom flask) sebesar $0,3 \mathrm{gr} / \mathrm{ml}$.

\section{Alat Utama}

Microwave oven yang digunakan Electrolux model EMM20K18GW (multimode), dengan daya maksimum $800 \mathrm{~W}$. Dimensi Microwave oven yang dilapisi PTFE : $p=45 \mathrm{~cm}, l=33 \mathrm{~cm}, \mathrm{t}=25 \mathrm{~cm}$. Kapasitas ruang 20 L. Microwave oven dimodifikasi dengan melepas turntable dan mengebor bagian bawah untuk membuat lubang yang menghubungkan dengan kondensor Liebig. Sisa lubang ditutup dengan lapisan PTFE untuk menghindari terjadinya kehilangan panas. Microwave oven dilengkapi sensor suhu (Thermocouple tipe $\mathrm{K}$ ), kontrol suhu digital, pengatur waktu dan daya. Reaktor Labu (round bottom flask) berkapasitas $1000 \mathrm{ml}$ dari bahan kaca pyrex dilengkapi dengan penyangga berpori, ditempatkan dengan posisi terbalik di dalam oven. Rangkaian alat bisa dilihat pada Gambar 1 .

\section{Metode Microwave Hydrodiffusion and Gravity (MHG) dan Prosedur Penelitian}

Prosedur MHG dilakukan pada tekanan atmosfer, 300 gram massa kulit jeruk segar yang sudah dicacah ditempatkan di dalam reaktor microwave dan dipanaskan menggunakan 3 variabel daya 136, 264, dan 440 Watt selama 15, 30, 45 dan 60 menit tanpa penambahan pelarut ataupun air. Selama percobaan suhu dipantau oleh sensor suhu. Variasi suhu bahan di dalam reaktor labu diukur secara kontinyu. Laju ektraksi dihitung dengan mengukur volume destilat (ml) yang diperoleh tiap 15 menit. Bahan akan menyerap radiasi microwave hingga mencapai kelenjar glandular bahan tanaman di dalam dinding sel. Proses ini menimbulkan panas sehingga dinding sel akan pecah dan minyak atsiri di dalamnya dapat terdifusi keluar. Interaksi langsung radiasi microwave dengan in situ water (yaitu, uap yang dihasilkan dari air yang ada dalam bahan tanaman segar) mendorong pelepasan minyak atsiri yang terperangkap di dalam sel-sel jaringan tanaman. Campuran minyak dan air akan terdifusi keluar dengan proses osmosis melalui selaput membran kulit jeruk sampai di permukaan untuk selanjutnya akan menguap [15].

Minyak atsiri kemudian akan turun secara gravitasi dari reaktor microwave melalui Pyrex disc yang berlubang. Sistem pendingin kondensor akan mendinginkan ekstrak minyak yang melewatinya secara kontinyue, sehingga air dan minyak atsiri yang terkondensasi terkumpul di florentine flask (corong pemisah) dan terpisah secara alami. Minyak atsiri yang lebih ringan densitasnya berada di atas lapisan air. Metode Microwave hydrodiffusion and gravity ini tanpa proses destilasi dan evaporasi, sehingga tidak terlalu banyak energy yang dibutuhkan [8]. Rangkaian alat MHG dapat dilihat pada gambar 1.

Minyak hasil ekstraksi yang sudah dipisahkan dari air dengan menggunakan corong pemisah (florentine flask), kemudian ditampung dalam tabung reaksi. $\mathrm{Na}_{2} \mathrm{SO}_{4}$ anhydrous ditambahkan ke dalam minyak untuk menyerap kadar airnya. Minyak kemudian ditimbang dan disimpan di botol sample dalam freezer (suhu $4^{\circ} \mathrm{C}$ ) sampai analisa dilakukan. Minyak dianalisa komposisinya dengan GC-MS 
untuk mengetahui jumlah oxygenated compounds (fraksi senyawa yang teroksigenasi). Hasil minyak atsiri kulit jeruk dihitung sesua dengan persamaan (1) [17].
Yield $(\%)=\frac{\text { Berat minyak yang dihasilkan }}{\text { Berat bahan baku awal (1-kadar air) }} \times 100 \%$

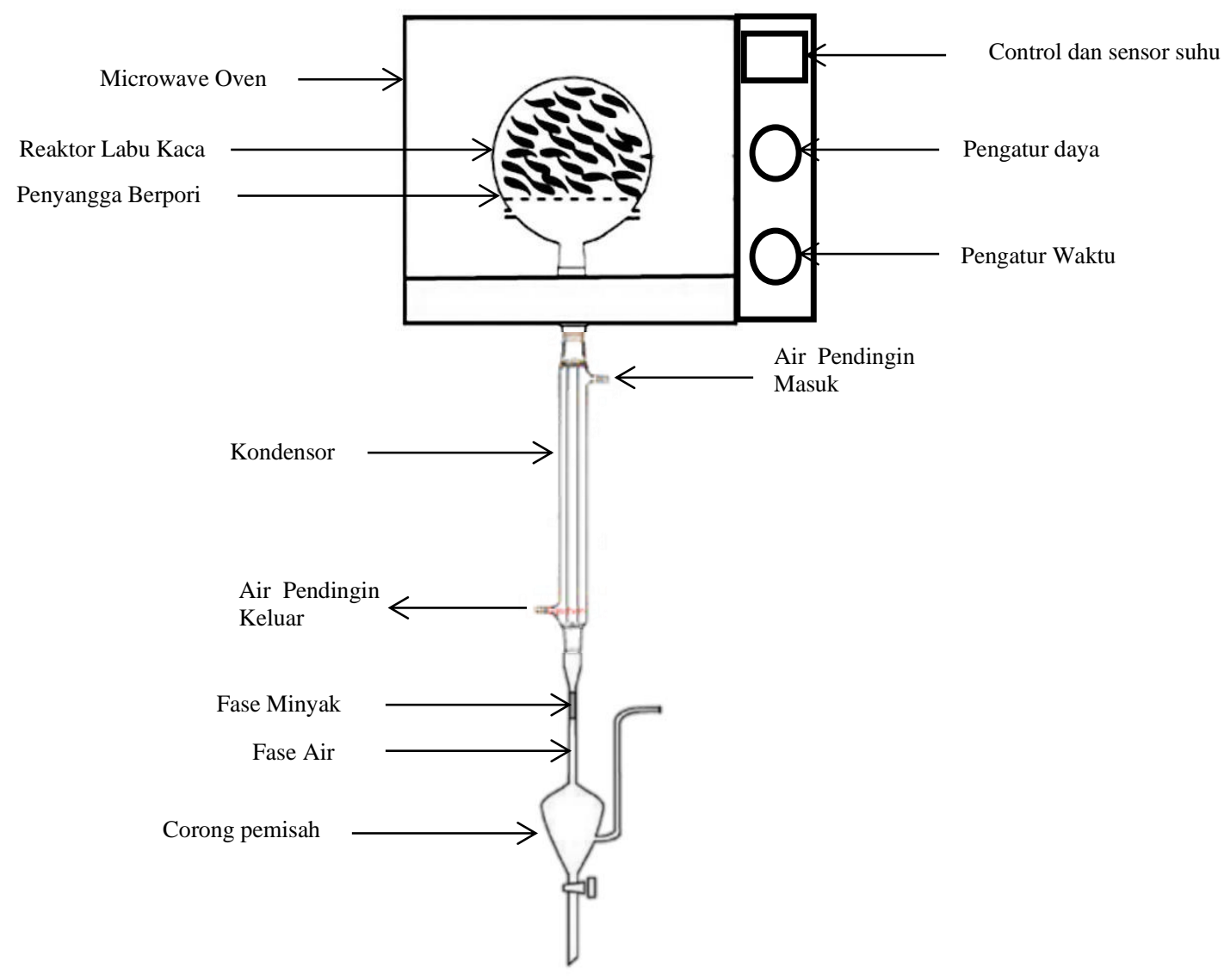

Gambar 1. Skema Alat Microwave Hydrodiffusion and Gravity (MHG)

\section{Metode Microwave Steam Diffusion dan Prosedur Penelitian}

Prinsip Kerjanya hampir sama dengan metode Microwave Hydrodiffusion and Gravity hanya saja terdapat penambahan steam generator (uap panas), yang berfungsi untuk memberi tambahan panas dan diharapkan dapat mempercepat proses ekstraksi minyak atsiri [16]. Dalam prosedur MSDf pada tekanan atmosfer secara batch 300 gram kulit jeruk segar dikemas ke dalam reaktor Pyrex. Steam diproduksi dari luar microwave, lalu dialirkan menuju bahan yang ada dalam reaktor labu, sedangkan bahan terus dipanaskan dalam ruang microwave dengan variasi daya 136 watt, 264 watt, dan 440 watt selama 15 menit, 30 menit, 45 menit, dan 60 menit. Laju ektraksi dihitung dengan mengukur volume destilat (ml) yang diperoleh tiap 15 menit. Kombinasi microwave dengan steam (uap jenuh) mendorong pelepasan minyak atsiri yang terperangkap di dalam sel-sel jaringan tanaman. Campuran minyak dalam in situ water dan steam bergerak secara alami ke bawah oleh gravitasi bumi ke dalam kondensor di luar rongga microwave. Ekstraksi dilanjutkan sampai tidak ada minyak atsiri yang diperoleh. Rangkaian alat MSDf dapat dilihat pada gambar 2 . 


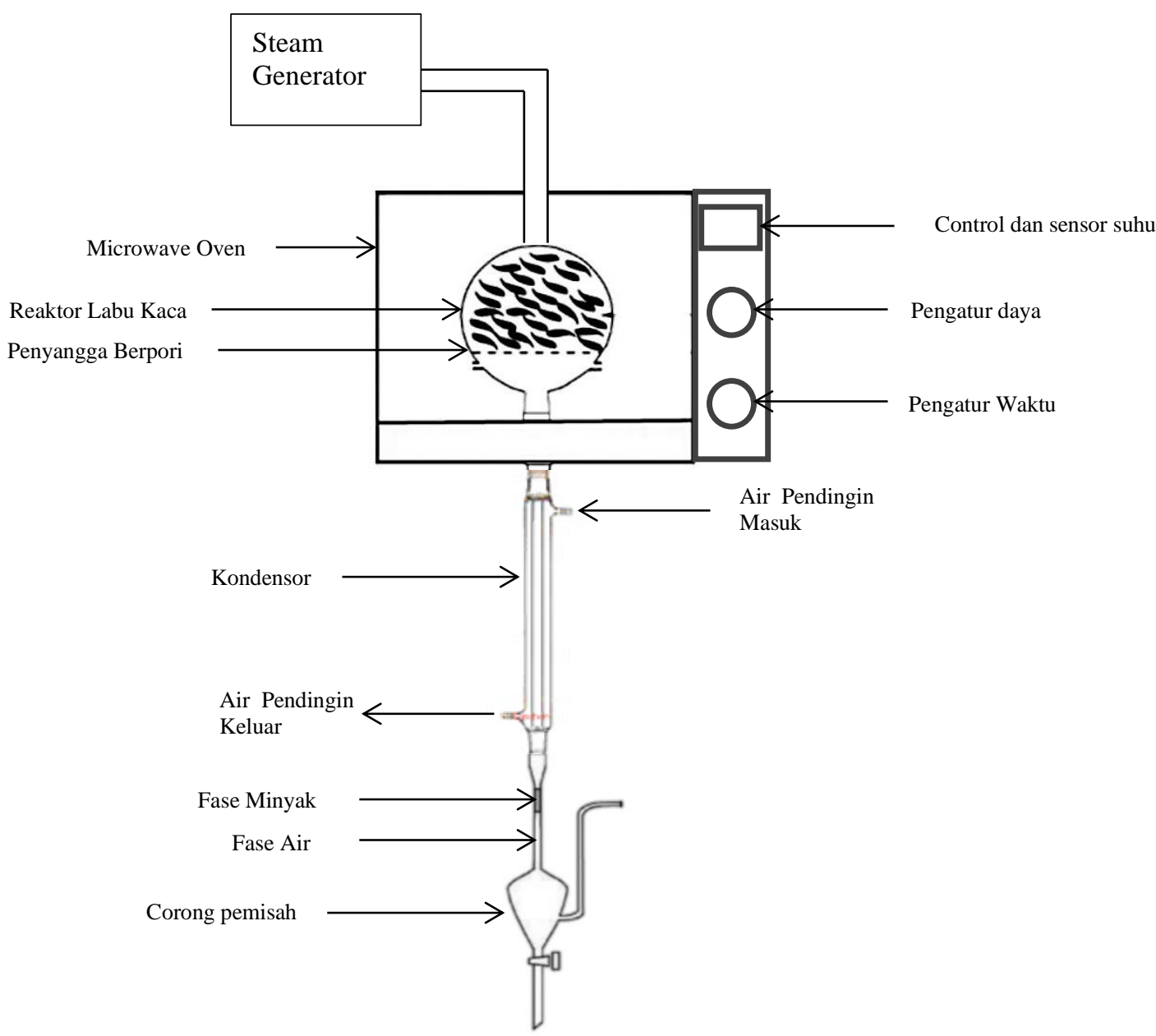

Gambar 2. Skema Alat Microwave Steam Diffusion (MSDf)

\section{Konsumsi Listrik (Electric Consumption)}

Konsumsi energi listrik dari berbagai metode ekstraksi yang berbeda dihitung berdasarkan pengaruh daya konsumsi dan waktu ekstraksi. Persamaan umum untuk konsumsi listrik disajikan dalam persamaan (2).

$$
E_{c}=\frac{P t}{3600000}
$$

keterangan :

$\mathrm{E}_{\mathrm{c}}=$ konsumsi listrik $(\mathrm{kWh})$,

$\mathrm{P}=$ konsumsi daya $(\mathrm{W})$ dan $\mathrm{t}=$ waktu $(\mathrm{s})$

\section{Emisi Gas $\mathrm{CO}_{2}$}

Perhitungan $\mathrm{CO}_{2}$ yang telah dikembangkan, sesuai dengan prosedur yang disebutkan dalam penelitian sebelumnya [6]. Untuk mendapatkan 1 $\mathrm{kWh}$ energi dari batu bara atau bahan bakar fosil, 800 $\mathrm{g} \mathrm{CO}_{2}$ akan dilepaskan ke atmosfer selama proses pembakaran [6]. Pehitungan emisi gas $\mathrm{CO}_{2}$ dijelaskan oleh persamaan (3).

$$
\begin{aligned}
E_{\mathrm{CO}_{2}} & =\frac{E_{\mathrm{C}} 800}{1000} \\
& \text { keterangan : } E_{\mathrm{CO}_{2}}=\text { emisi gas } \mathrm{CO}_{2}(\mathrm{~kg}), \\
& \mathrm{E}_{\mathrm{c}}=\text { konsumsi listrik }(\mathrm{kWh})
\end{aligned}
$$

Identifikasi GC-MS (Gas Chromatography-Mass Spectrometry)

Komposisi minyak atsiri ditentukan oleh gas chromatography digabungkan dengan analisis spektrometri massa (GC-MS). Agilent 6890N gas chromatograph dan Agilent 5973 mass spectrometric detector digunakan untuk GCMS. Menggunakan kolom kromatografi HP-5\% Phenyl Methyl Siloxane, panjang $30 \mathrm{~m}$, ketebalan film $0,32 \mu \mathrm{m}$, diameter internal $250 \mu \mathrm{m}$. Program suhu oven dari $50^{\circ} \mathrm{C}$ hingga $325^{\circ} \mathrm{C}$ pada laju kenaikan suhu $10^{\circ} \mathrm{C}$ per menit dengan helium sebagai gas pembawa. Volume injeksi $1 \mu$, 
suhu injeksi $300^{\circ} \mathrm{C}$, split flow $50 \mathrm{~mL} / \mathrm{menit}$, dan total waktu run 20 menit.

\section{Hasil dan Pembahasan}

Pengaruh daya Microwave dan lamanya waktu ekstraksi terhadap Yield Minyak Atsiri

Daya microwave yang digunakan dalam proses ekstraksi menggunakan metode MHG dan MSDf terkait erat dengan suhu pemrosesan. Daya yang tinggi dapat menaikkan suhu operasi dan menghasilkan peningkatan yield hasil ekstraksi. Daya microwave berperan sebagai driving force untuk memecah struktur membran sel tanaman, sehingga minyak dapat terdifusi keluar. Peningkatan besaran daya secara umum akan meningkatkan jumlah yield dan mempercepat waktu ekstraksi [18]. Hal ini disebabkan perpindahan massa dan panas yang terjadi pada metode MHG dan MSDf, bekerja dalam arah yang sama yaitu dari dalam bahan menuju ke luar permukaan bahan. Perpindahan energi microwave terjadi secara radiasi menuju bahan melalui interaksi molekuler bahan dengan medan elektromagnetik yang dihasilkan oleh microwave, selanjutnya dikonversi menjadi energi panas. Sehingga kombinasi sinergis dua fenomena perpindahan ini mempercepat proses difusi minyak menuju permukaan bahan [19].

Besarnya suhu operasi dan laju/ kecepatan ekstraksi dipengaruhi oleh besarnya daya yang dipasang. Suhu operasi yang tercatat selama proses ekstraksi tergantung oleh daya yang digunakan. Tabel 1 dan 2 menunjukkan bahwa metode MSDf lebih cepat menghasilkan yield pada menit-menit awal proses ekstraksi bila dibandingkan dengan metode MHG. Total yield yang dihasilkan pun lebih banyak daripada metode MHG. Hal ini disebabkan adanya penambahan steam yang berperan dalam membantu penetrasi uap panas ke dalam bahan, sehingga komponen minyak penting yang berada di dalam membran sel/ jaringan tanaman bisa cepat ikut terdifusi keluar bersama uap dan air. Hal ini sesuai dengan penelitian Farhat (2011) yang menyatakan bahwa laju alir massa uap (steam) memiliki pengaruh paling penting pada lamanya waktu ekstraksi diikuti oleh daya microwave, interaksi daya microwave dan laju aliran massa uap (steam) [16].

Berikut tabel 1 dan 2 yang menyajikan data suhu operasi, laju ekstraksi, dan yield minyak pada masingmasing metode MHG dan MSDf.

Tabel 1. Perbandingan Yield yang diperoleh pada 3 variasi daya microwave menggunakan metode MHG

\begin{tabular}{|c|c|c|c|c|c|c|c|c|c|}
\hline \multirow{2}{*}{$\begin{array}{c}\text { Waktu } \\
\text { Ekstraksi } \\
(\mathbf{m e n i t})\end{array}$} & \begin{tabular}{c} 
136 W \\
\cline { 2 - 11 } \\
$\mathbf{b a h a n}$ \\
$\left({ }^{\mathbf{O}} \mathbf{C}\right)$
\end{tabular} & $\begin{array}{c}\text { Laju } \\
\text { Ekstraksi } \\
(\mathbf{m l} / \mathbf{m e n i t})\end{array}$ & $\begin{array}{c}\text { Yield } \\
(\%)\end{array}$ & $\begin{array}{c}\text { Suhu } \\
\text { bahan } \\
\left({ }^{\mathbf{O}} \mathbf{C}\right)\end{array}$ & $\begin{array}{c}\text { Laju } \\
\text { Ekstraksi } \\
(\mathbf{m l} / \mathbf{m e n i t})\end{array}$ & $\begin{array}{c}\text { Yield } \\
(\%)\end{array}$ & $\begin{array}{c}\text { Suhu } \\
\text { bahan } \\
\left({ }^{\mathbf{O}} \mathbf{C}\right)\end{array}$ & $\begin{array}{c}\text { Laju } \\
\text { Ekstraksi } \\
(\mathbf{m l} / \mathbf{m e n i t})\end{array}$ & $\begin{array}{c}\text { Yield } \\
(\%)\end{array}$ \\
\hline 0 & 0 & 0 & 0 & 0 & 0 & 0 & 0 & 0 & 0 \\
\hline 15 & 84 & 2,2 & 0,93 & 95 & 2,67 & 1,4 & 99 & 1,97 & 0,68 \\
\hline 30 & 95 & 1,5 & 0,27 & 99 & 1,8 & 0,37 & 104 & 1,6 & 0,38 \\
\hline 45 & 100 & 0,5 & 0,14 & 100 & 0.7 & 0,16 & - & - & - \\
\hline 60 & 100 & 0,2 & 0,01 & 101 & 0,4 & 0,02 & - & - & - \\
\hline
\end{tabular}

Tabel 2. Perbandingan Yield yang diperoleh pada 3 variasi daya microwave menggunakan metode MSDf

\begin{tabular}{|c|c|c|c|c|c|c|c|c|c|}
\hline \multirow{2}{*}{$\begin{array}{c}\text { Waktu } \\
\text { Ekstraksi } \\
(\text { menit })\end{array}$} & $\begin{array}{c}\text { Suhu } \\
\text { bahan } \\
\left({ }^{\mathbf{O} C)}\right.\end{array}$ & $\begin{array}{c}\text { Laju } \\
\text { Ekstraksi } \\
(\mathbf{m l} / \mathbf{m e n i t})\end{array}$ & $\begin{array}{c}\text { Yield } \\
(\%)\end{array}$ & $\begin{array}{c}\text { Suhu } \\
\text { bahan } \\
\left({ }^{\mathbf{O}} \mathbf{C}\right)\end{array}$ & $\begin{array}{c}\text { Laju } \\
\text { Ekstraksi } \\
(\mathbf{m l} / \mathbf{m e n i t})\end{array}$ & $\begin{array}{c}\text { Yield } \\
(\%)\end{array}$ & $\begin{array}{c}\text { Suhu } \\
\text { bahan } \\
\left({ }^{\mathbf{O}} \mathbf{C}\right)\end{array}$ & $\begin{array}{c}\text { Laju } \\
\text { Ekstraksi } \\
(\mathbf{m l} / \mathbf{m e n i t})\end{array}$ & $\begin{array}{c}\text { Yield } \\
(\%)\end{array}$ \\
\hline 0 & 0 & 0 & 0 & 0 & 0 & 0 & 0 & 0 & 0 \\
\hline 15 & 90 & 2,1 & 1,2 & 98 & 2,7 & 1,9 & 100 & 2,4 & 0,95 \\
\hline 30 & 100 & 1,15 & 0,13 & 104 & 1,2 & 0,24 & 105 & 1,3 & 0,14 \\
\hline 45 & 99 & 0,3 & 0,06 & 102 & 0,3 & 0,02 & 103 & 0,4 & 0,03 \\
\hline 60 & 98 & 0,1 & 0,01 & 100 & 0,2 & 0,01 & 101 & 0,2 & 0,01 \\
\hline
\end{tabular}


Pada metode MSDf diberikan penambahan uap basah (wet steam) yang berpengaruh terhadap suhu uap dalam sistem (labu distiller), yaitu menjaga suhu operasi agar tidak melebihi suhu uap jenuh (saturated vapor) pada tekanan 1 atmosfer. Sehingga terjadinya kehangusan pada bahan dapat dicegah. Oleh karena itu, meskipun menggunakan daya $440 \mathrm{~W}$, proses ekstraksi dapat terus berlangsung selama 1 jam tanpa terjadi kehangusan pada bahan. Berbeda halnya dengan metode MHG yang mengalami kehangusan pada daya $440 \mathrm{~W}$ di atas 30 menit. Penambahan uap basah (wet steam) ini juga berperan dalam membantu penetrasi uap panas ke dalam bahan, sehingga komponen minyak penting yang berada di dalam membran sel/ jaringan tanaman bisa ikut terdifusi keluar bersama uap dan air. Namun ketika suhu sistem turun, akibatnya sejumlah besar uap basah yang ditambahkan ke dalam system akan terkondensasi dalam tumpukan bahan, sehingga bahan bertambah basah.

Ilustrasi proses penurunan suhu sistem ketika ada penambahan steam dapat dilihat pada gambar 1 . Jika terjadi pembasahan bahan yang berlebihan akibat terkondensasinya uap jenuh ini, maka akan berakibat pada terbentuknya gumpalan bahan (bahan menggumpal). Sehingga ruang antar bahan akan hilang (tidak bersifat porous) dan uap akan sulit menembus (berpenetrasi) ke dalam bahan, mengakibatkan laju penguapan/penyulingan menjadi lambat dan yield yang dihasilkan menjadi lebih sedikit [20].

Steam diproduksi dari air yang dipanaskan secara terus menerus di luar alat microwave oven.
Kemudian dialirkan ke dalam tumpukan bahan yang berada di dalam microwave oven. Steam yang memiliki fase gas tidak dapat menyerap radiasi microwave, karena pada fase gas molekul-molekulnya saling berjauhan sehingga kecil kemungkinannya terjadi friksi/ tumbukan antar molekul. Fungsi steam di sini adalah menyediakan energi panas untuk bahan dalam sistem dan sebagai medium perpindahan bagi komponen minyak atsiri dalam bahan untuk dapat menguap. Sehingga berdampak pada peningkatan komponen senyawa penting dalam minyak yang dapat terekstrak [20].

Secara umum terlihat bahwa kenaikan suhu tertinggi ditemukan di daya microwave $440 \mathrm{~W}$. Namun, dalam proses ekstraksi menggunakan pemanas microwave, ada faktor karakteristik bahan yang mempengaruhi proses ekstraksi yang disebut dengan konstanta dielektrik suatu bahan. Konstanta dielektrik material berperan dalam menentukan interaksi antara medan listrik dan molekul bahan [19]. Keberadaan konstanta dielektrik ini membuat ekstraksi menggunakan daya microwave $440 \mathrm{~W}$ tidak serta merta memberikan hasil terbaik. Dalam studi ini terlihat bahwa daya microwave terbaik untuk menghasilkan minyak atsiri yang optimal adalah 264 W. Ekstraksi yang dilakukan pada daya microwave $440 \mathrm{~W}$ memperoleh yield lebih rendah bila dibandingkan dengan daya microwave 264 W. Faktor lain yang dapat menyebabkan penurunan hasil pada daya microwave $440 \mathrm{~W}$ adalah terjadinya degradasi bahan tanaman dan komponen minyak atsiri serta hilangnya senyawa volatile penting yang terkandung dalam bahan [21].

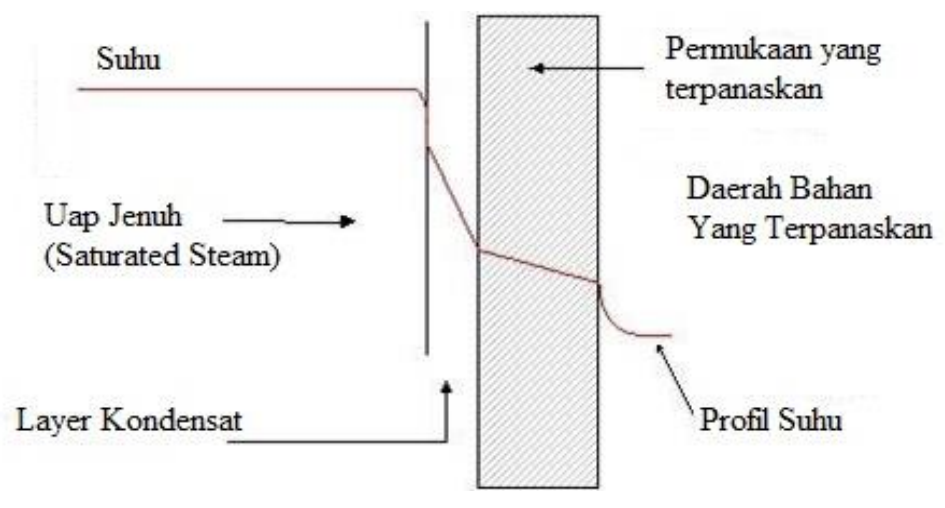

Gambar 1. Profil Suhu di Permukaan Lapisan Bahan yang diberikan Penambahan Wet Steam (Saturated Steam) pada Metode MSDf 


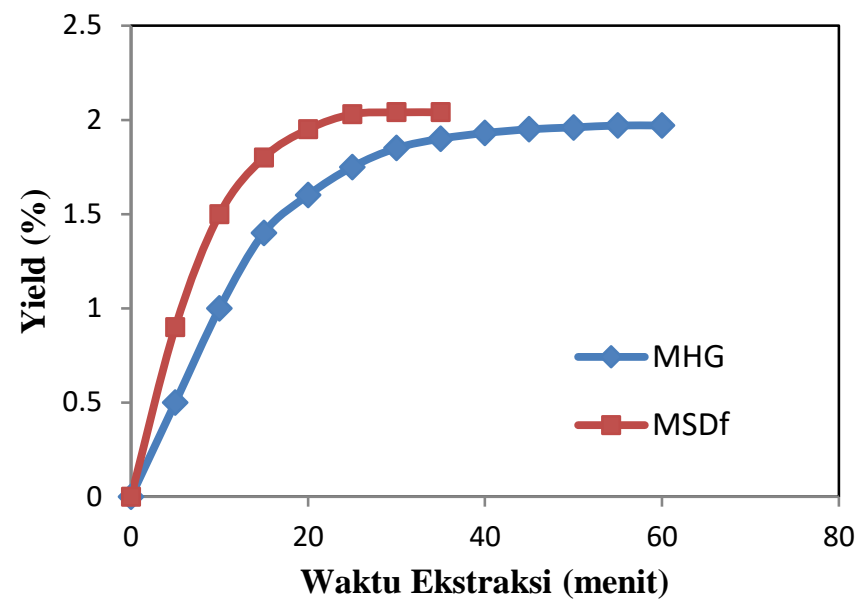

Gambar 2. Hubungan Waktu Ekstraksi dan \% Yield Minyak Atsiri pada Daya 264 W

Gambar 2 menunjukkan hubungan $\%$ yield dan waktu ekstraksi metode MSDf dibandingkan dengan metode MHG pada daya optimal 264 W. Pada metode MSDf menit ke 20 menghasilkan \% yield minyak sebesar $1,95 \%$, sedangkan metode MHG baru bisa mendapatkan $1,93 \%$ pada menit ke 40 .

\subsection{Hasil Analisa Komposisi Kimia Minyak Kulit jeruk}

Tabel 3 menunjukkan komposisi kimia minyak atsiri jeruk yang dihasilkan dari metode MHG dan MSDf. Besarnya jumlah senyawa teoksigenasi (oxygenated compounds) dalam minyak atsiri berperan dalam meningkatkan aroma minyak menjadi lebih harum, sehingga senyawa teroksigenasi ini lebih bernilai. Komponen yang dominan dalam minyak atsiri jeruk adalah Limonene yang termasuk golongan monoterpene hydrocarbon. Hanya saja golongan monoterpene hydrocarbon dan sesquiterpen hydrocarbon ini termasuk non-oxygenated compounds yang kurang bernilai karena hanya sedikit berperan dalam memberikan keharuman pada minyak.

Minyak atsiri pada umumnya mengandung senyawa-senyawa organik yang mampu menyerap kuat energi microwave. Senyawa organik (oxygenated compounds) yang memiliki momen dipol tinggi akan berinteraksi lebih kuat dengan microwave sehingga dapat diekstrak lebih mudah dibandingkan dengan senyawa aromatik yang memiliki momen dipol rendah (seperti monoterpene hydrocarbon) [19]. Tabel 3 menunjukkan bahwa jumlah oxygenated compounds yang diperoleh dari metode MSDf $(1,4 \%)$ lebih besar daripada metode MHG (1,12\%). Hal ini menunjukkan bahwa metode MSDf mampu menghasilkan kualitas minyak yang sama seperti metode MHG. Meskipun \% yield minyak yang dihasilkan metode MSDf pada menit ke 20 setara dengan $\%$ yield metode MHG pada menit ke 40.

Tabel 3. Hasil Analisa komposisi kimia minyak atsiri jeruk dengan GCMS

\begin{tabular}{|l|c|c|}
\hline \multicolumn{1}{|c|}{ Senyawa } & $\begin{array}{c}\text { \% Massa MHG } \\
\mathbf{( 2 6 4} \mathbf{~ W )}\end{array}$ & $\begin{array}{c}\text { \% Massa MDSf } \\
\mathbf{( 2 6 4} \mathbf{~ W})\end{array}$ \\
\hline Monoterpenes & 97,57 & 98,33 \\
\hline Oxygenated Monoterpenes & 0,56 & 0,64 \\
\hline Sesquiterpenes & 0,19 & 0,23 \\
\hline Oxygenated Sesquiterpenes & 0,05 & 0,08 \\
\hline Other Oxygenated Compounds & 0,31 & 0,43 \\
\hline Total Oxygenated Compounds & 1,12 & 1,4 \\
\hline Total Non-Oxygenated Compounds & 98,21 & 98,56 \\
\hline Lama Ektraksi (menit) & 40 & 20 \\
\hline \% Yield & 1,93 & 1,95 \\
\hline
\end{tabular}


Pada Tabel 4 menunjukkan perbandingan energi listrik yang dikonsumsi dan emisi gas $\mathrm{CO}_{2}$ yang dihasilkan kedua metode. Metode MSDf lebih hemat energy $3 \%$ dibandingkan dengan metode MHG. Emisi $\mathrm{Gas} \mathrm{CO}_{2}$ yang dilepas ke udara pada metode MSDf juga lebih sedikit daripada MHG, sehingga dampak ke lingkungan tidak terlalu besar.

Tabel 4. Konsumsi Energi Listrik yang dibutuhkan dan emisi gas $\mathrm{CO}_{2}$ antara Metode MHG dan MHD

\begin{tabular}{|c|c|c|}
\hline Yang dibandingkan & $\begin{array}{c}\text { MHG } \\
\mathbf{( 2 6 4} \mathbf{~ W})\end{array}$ & $\begin{array}{c}\text { MSDf (Microwave } \\
\text { + Steam } \\
\text { Generator) } \\
(\mathbf{2 6 4} \mathbf{~ W}+\mathbf{2 5 0} \mathbf{~ W})\end{array}$ \\
\hline Waktu Ekstraksi (menit) & 40 & 20 \\
\hline$E_{c} /$ Konsumsi Energi $(\mathrm{kWh})$ & 0,176 & 0,171 \\
\hline$E_{\mathrm{CO}_{2}} /$ Emisi Gas $\mathrm{CO}_{2}(\mathrm{~kg})$ & 0,1408 & 0,1368 \\
\hline
\end{tabular}

\section{Kesimpulan}

Metode MSDf menghasilkan yield lebih cepat dibandingkan dengan metode $\mathrm{MHG}$ pada daya optimal 264 W. Pada menit ke 20, metode MSDf menghasilkan yield minyak atsiri sebesar $1,95 \%$, sedangkan metode MHG menghasilkan 1,93\% yield pada menit ke 40. Metode MSDf meghasilkan jumlah oxygenated compounds $(1,4 \%)$ lebih besar daripada metode MHG $(1,12 \%)$. Berdasarkan perbandingan energi listrik yang dikonsumsi, metode MSDf lebih hemat energy $3 \%$ dibandingkan dengan metode MHG. Emisi Gas $\mathrm{CO}_{2}$ yang dilepas ke udara pada metode MSDf juga lebih sedikit daripada metode MHG, sehingga dampak ke lingkungan tidak signifikan.

\section{Ucapan Terima Kasih}

Ucapan terimakasih disampaikan kepada LPPM Universitas Tribhuwana Tunggadewi yang telah mendukung pendanaan penelitian. Penelitian ini dapat terlaksana dengan baik atas pendanaan dari Hibah Penelitian Universitas Tribhuwana Tunggadewi tahun 2020.

\section{Daftar Pustaka}

[1] V. Oreopoulou and C. Tzia, "Utilization of plant by-products for the recovery of proteins, dietary fibers, antioxidants, and colorants," in Utilization of By-Products and Treatment of Waste in the Food Industry, 2007.

[2] S. Yeoh, J. Shi, and T. A. G. Langrish, "Comparisons between different techniques for water-based extraction of pectin from orange peels," Desalination, 2008.

[3] R. Suryani, OUTLOOK JERUK Komoditas Pertanian Sub Sektor Hortikultura. 2016.

[4] M. A. Ferhat, B. Y. Meklati, F. Visinoni, M. A. Vian, and F. Chemat, "Solvent free microwave extraction of essential oils Green chemistry in the teaching laboratory," Chim. Oggi, 2008.

[5] M. A. Ferhat, B. Y. Meklati, and F. Chemat, "Comparison of different isolation methods of essential oil from Citrus fruits: Cold pressing, hydrodistillation and microwave 'dry' distillation," Flavour Fragr. J., 2007.

[6] M. A. Ferhat, B. Y. Meklati, J. Smadja, and F. Chemat, "An improved microwave Clevenger apparatus for distillation of essential oils from orange peel," J. Chromatogr. A, 2006.

[7] L. Braun and M. Cohen, Herbs \& Natural Supplements: An evidence-base guide Volume 1. 2015.

[8] M. Sawamura, Citrus Essential Oils: Flavor and Fragrance. 2010.

[9] W. M. Nelson, "Green solvents for chemistry: perspectives and practice," Choice Rev. Online, vol. 41, no. 06, pp. 41-3457-41-3457, Feb. 2004.

[10] G. Cravotto, L. Boffa, S. Mantegna, P. Perego, M. Avogadro, and P. Cintas, "Improved extraction of vegetable oils under highintensity ultrasound and/or microwaves," Ultrason. Sonochem., 2008.

[11] J. A. Pérez-Serradilla, R. Japón-Luján, and M. D. Luque de Castro, "Simultaneous microwave-assisted solid-liquid extraction of polar and nonpolar compounds from alperujo," Anal. Chim. Acta, 2007.

[12] M. Romdhane and C. Gourdon, "Investigation in solid-liquid extraction: Influence of ultrasound," Chem. Eng. J., 2002.

[13] M. A. Vian, X. Fernandez, F. Visinoni, and F. Chemat, "Microwave hydrodiffusion and gravity, a new technique for extraction of essential oils," J. Chromatogr. A, 2008.

[14] C. C. Teo, S. N. Tan, J. W. H. Yong, C. S. Hew, and E. S. Ong, "Evaluation of the extraction efficiency of thermally labile bioactive compounds in Gastrodia elata Blume by pressurized hot water extraction and microwave-assisted extraction, "J. Chromatogr. A, 2008.

[15] N. Bousbia, M. Abert Vian, M. A. Ferhat, E. Petitcolas, B. Y. Meklati, and F. Chemat, "Comparison of two isolation methods for essential oil from rosemary leaves: Hydrodistillation and microwave hydrodiffusion and gravity, "Food Chem., 2009.

[16] A. Farhat, A. S. Fabiano-Tixier, M. El Maataoui, J. F. Maingonnat, M. Romdhane, and F. Chemat, "Microwave steam diffusion for extraction of essential oil from orange peel: Kinetic data, extract's global yield and mechanism," Food Chem., 2011.

[17] F. Chen, Y. Zu, and L. Yang, "A novel approach for isolation of essential oil from fresh leaves of Magnolia sieboldii using 
microwave-assisted simultaneous distillation and extraction," Sep. Purif. Technol., 2015.

[18] Z. Hu, M. Cai, and H. H. Liang, "Desirability function approach for the optimization of microwave-assisted extraction of saikosaponins from Radix Bupleuri," Sep. Purif. Technol., 2008.

[19] A. C. Kartika Fitri and F. K. Widyastuti, "Perbandingan metode microwave hydrodistillation (MH) dan microwave hydrodiffusion and gravity (MHG) untuk mengekstrak minyak atsiri dari kulit jeruk," Reka Buana J. Ilm. Tek. Sipil dan Tek. Kim., 2017.

[20] E. Guenther, "The Essential Oils: Historyorigin in plants production-analysis," Vol.l. fouth printing. 2011.

[21] H. S. Kusuma and M. Mahfud, "Box-Behnken design for investigation of microwave-assisted extraction of patchouli oil," in AIP Conference Proceedings, 2015. 